International Journal of Research in Engineering and Innovation
(IJREI)
journal home page: http://www.ijrei.com

\title{
Comparative study of mixing and under-flow air distribution system in an aircraft cabin using CFD
}

\author{
Chanfiou Ahmed Mboreha1*, Somashekar V², Gaurav Kumar ${ }^{3}$, Collins Nwaokocha ${ }^{4}$, Abayomi Layenil ${ }^{4}$ \\ ${ }^{I}$ Department of Aeronautical Engineering, Nanjing University of Aeronautics and Astronautics, Jiangsu, Nanjing, China \\ ${ }^{2}$ Department of Aeronautical Engineering, Acharya Institute of Technology, Bengaluru, India \\ ${ }^{3}$ Department of Mechanical Engineering, Delhi Technological University Delhi, India \\ ${ }^{4}$ Department of Mechanical Engineering, Olabisi Onabanjo University, Ago-Iwoye, Nigeria.
}

\begin{abstract}
The ventilation systems in commercial aircraft cabins are important for providing a healthy and comfortable environment for the passengers and crew. The mixing ventilation system currently used provides a uniform air temperature distribution in the cabin. It is therefore necessary to improve the current design of ventilation systems for aircraft cabins. Providing thermal comfort and good air quality are important factors to create a healthy and comfortable environment for passengers in airplane. By using a validated Computational Fluid Dynamics (CFD) program to simulate the cabin environment for a Boeing 767 airplane during cruise flight, this paper compares and analyzes the simulated cabin environment with mixing and under-floor displacement systems. Temperature and velocity distributions are discussed; also PMV and PPD are used to predict the thermal sensation of passengers. It was found that the mixing ventilation systems increase the air velocity in the cabin, makes the temperature distribution more uniform, and provide thermal comfort for passenger on his demand. It is observed that the PMV and PPD for the Mixing ventilation system were high in comparison with the displacement. The sensation for the displacement was Neutral, whereas the sensation in the mixing system was slightly cool.

Keywords: Aircraft cabin, Thermal comfort, CFD, Mixing ventilation, Displacement ventilation; PMV, PPD
\end{abstract}

\section{Nomenclature}

CFD $=$ Computational Fluid Dynamics

$\mathrm{PMV}=$ Predicted Mean Vote

PPD $=$ Predicted Percentage Dissatisfied

$\mathrm{ICL}=$ Clothing insulation

$\mathrm{FCL}=$ Clothing surface area factor

$\mathrm{TA}=$ Air Temperature

$\operatorname{Tr}=$ Mean radiant temperature

$\mathrm{HC}=$ Convective Heat Transfer coefficient

$\mathrm{VA}=$ Relative Velocity

$\mathrm{TCL}=$ Clothing surface temperature

\section{Introduction}

As we all know at high altitudes the pressure and temperature decrease, airplanes cruise at altitudes ranged from 35,000 to $37,000 \mathrm{ft}$, the outer environment becomes un-survivable by humans; For example, at $35,000 \mathrm{ft}$ the temperature decreases to $55^{\circ} \mathrm{C}\left(65^{\circ} \mathrm{F}\right)$, the ambient pressure becomes $10.1 \mathrm{KPa}(1.5 \mathrm{psi})$, and water content are dry (National Academy of Sciences,2002). Traveling by air is increasing by huge percentage, more than 1 billion passengers annually, 5\% of these travels are to the developing world (Ryan, E.T,2011), in order to protect those passengers from the outer environment and provide them comfort environment an Environmental Control System (ECS) is needed. Commercial airplanes work in an extreme ambient environment during cruise flight, so an environmental control system is needed to provide a suitable cabin environment (NRC. 2001). As a part of the environmental control system, the air distribution system

*Corresponding author: Chanfiou Ahmed Mboreha

Email Address: chafi01@yandex.com 
delivers conditioned air to the cabin. The air distribution system currently used for commercial aircraft is mixing ventilation. This system provides a uniform air temperature distribution and dilutes contaminants in the cabin. However, the mixing ventilation system could spread infectious airborne diseases such as influenza and SARS. Thus it is necessary to improve the design of ventilation systems currently used for aircraft cabins. All modern airplanes air distribution systems consist of 50\% filtered recirculated air and 50\% outside air, the recirculated air is sterilized by high efficiency particulate air type filters (HEPAtype) which removes $99.9 \%$ of the bacteria and viruses produced by the passengers (Hunt, E.H.,1995). Nowadays, all the airlines companies are concerned with achieving the thermal comfort for passengers as much as they can, many studies were done on different air distribution systems trying to reach the best design that could provide acceptable air quality and comfort environment inside the aircraft cabin. (Chen and Zhang compared between three air distribution systems (mixing, under-floor displacement, and personalized) in a section of a Boeing 767-300 cabin). For the mixing air distribution, the mixed conditioned air (5 1/s outside air and $5 \mathrm{l} / \mathrm{s}$ recirculated air) is supplied from two ceiling inlets with high velocity and extracted through two floor outlets near the side walls at the floor level. The under-floor displacement distribution inlets are along the aisles supplying the same air mixture as in the mixed distribution system, while the outlets were two ceiling outlets. In the personalized air distribution system, the inlets were along the aisles and additional inlets were located at the seat-back in front of each passenger, the air is extracted through two ceiling outlets. In the displacement air distribution system there was a chance of mixing in the center seating which might be a reason for spreading the infectious diseases. Hence this paper is concerned with the study of the air distribution in aircraft cabin and also trying to improve the thermal comfort for the passengers by numerical simulation comparison between the Mixing Ventilation and the displacement systems.

\section{Validation of a CFD program}

AIAA defines validation as "The process of determining the degree to which a (CFD) model is an accurate representation of the real world from the perspective of the intended uses of the model"(AIAA,1998). Based the review above, this investigation selected CFD as the research tool used to compare the performance of different ventilation systems for an aircraft cabin.

Previous studies (Aboosaidi F,1991; Garner R.,2003) show that FLUENT (Anon) has performed reasonably well, and thus it was selected for the present study. Although FLUENT is being validated elsewhere, it is important that the software should be validated together with the user (Chen Q.,2002). Since most of the experimental data for aircraft cabins available from the literature do not provide detailed information, the validation process discussed in this paper used the air flow, and temperature data obtained from a small office as shown in Figure 1 (Yuan X.,1999). This study also selected a RANS model to compare air distributions with different air supply systems. The RANS model is the renormalization group (RNG) $\mathrm{k}-\varepsilon$ model (Yakhot V.,1992). Like any other RANS model, the RNG k- $\varepsilon$ model uses a lot of approximations.

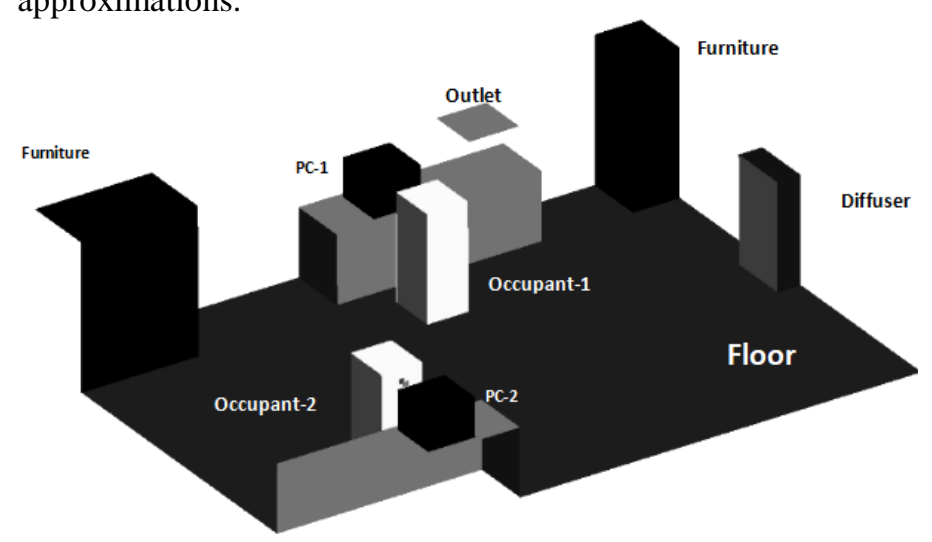

Figure 1: The office configuration used for CFD program validation

This office configuration has similar flow characteristics to those found in an aircraft cabin. For example, the turbulent flow is mixed convection where both inertial and buoyant forces are important. Figure 2 compares the airflow pattern in the mid-plane along the Y-direction. The airflow pattern computed by CFD is similar to that visualized in the experiment. The CFD can correctly reproduce the recirculation in the low part of the room. The magnitude of the air velocity also reflects a good comparison between the CFD results and smoke visualization. The quantitative comparison for air velocity and air temperature was only presented at the center of the office as shown in Figure 3. The results in other locations are very similar to those shown in Figure 3 . The air velocities were measured by omni-directional anemometers. It is difficult to measure an air velocity lower than $0.1 \mathrm{~m} / \mathrm{s}$ because the convection from the anemometer probe would generate a false velocity of the same magnitude. The uncertainty for the measured air velocities was 10\% of the readings. The error for air temperature measurements was $0.4 \mathrm{~K}$ (Srebric J.,2002). The agreement between the CFD results and the experimental data is very good for the air temperature, reasonably good for the air velocity in some locations.

The comparison of the CFD results with experimental data concludes that the CFD program with the RNG $\mathrm{k}-\varepsilon$ model is a good tool that can reasonably well predict airflow and air temperature in an enclosure with mixed convection. Although there are discrepancies between the computed results and measured data, the CFD model can be used as a tool to analyze air distribution in an aircraft cabin.

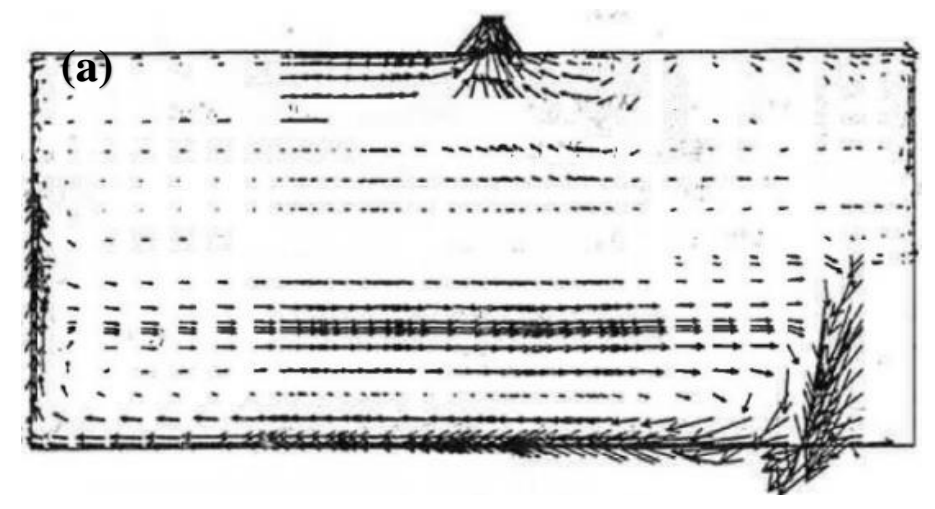




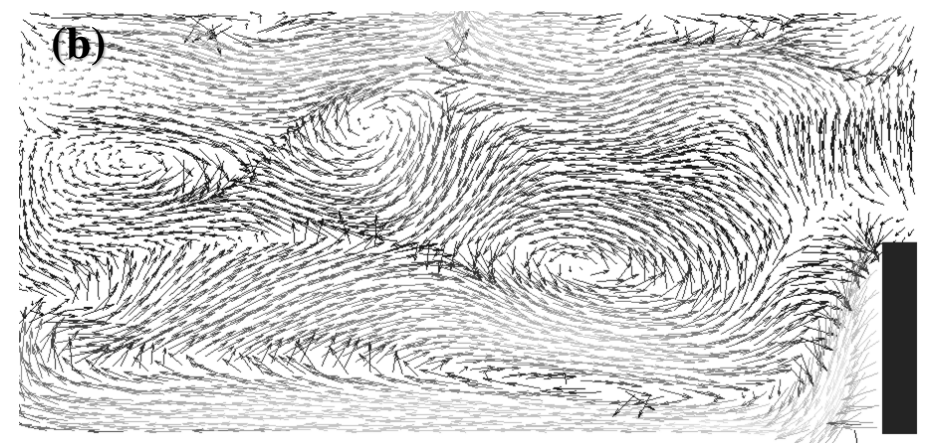

Figure 2: The airflow pattern observed by smoke visualization (a) and computed by $C F D(b)$ in the mid-plane along the $Y$-direction.
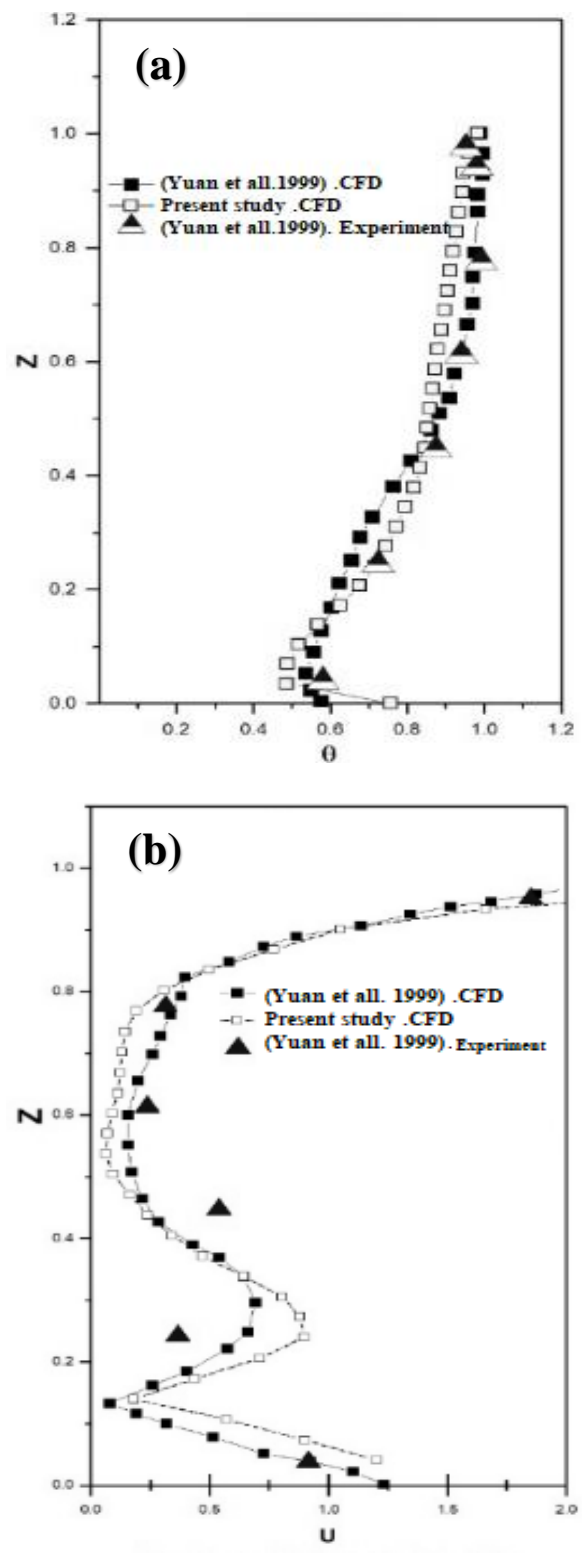

Figure 3: The comparison of the profiles of air temperature (a) and air velocity $(b)$ between the CFD results and experimental data at the center of the office.

\section{Numerical simulation of the aircraft cabin}

\subsection{Geometry and boundary conditions}

With the validated CFD program, the airflow in a section of a Boeing 767-300 cabin during cruise flight, shown in Figure 4b-c, were studied. The cabin contains four rows of seats with all seats assumed to be occupied. According to a previous research (Topp C.,2002), a box-shaped manikin is sufficient for the study of global airflow in the space. Therefore, the box-shape manikins were selected to represent the passengers in cabin.

This study compared two different ventilation methods: mixing and, displacement ventilation systems. In the mixing ventilation, two ceiling inlets supplied conditioned air at high velocities, and two floor outlets extracted air near the side walls as can be seen in figure 4-c. The displacement ventilation used perforated aisle inlets to supply conditioned air and two ceiling outlets to extract air as can be seen in figure 4-b. Table 1 shows the boundary conditions for the two ventilation schemes
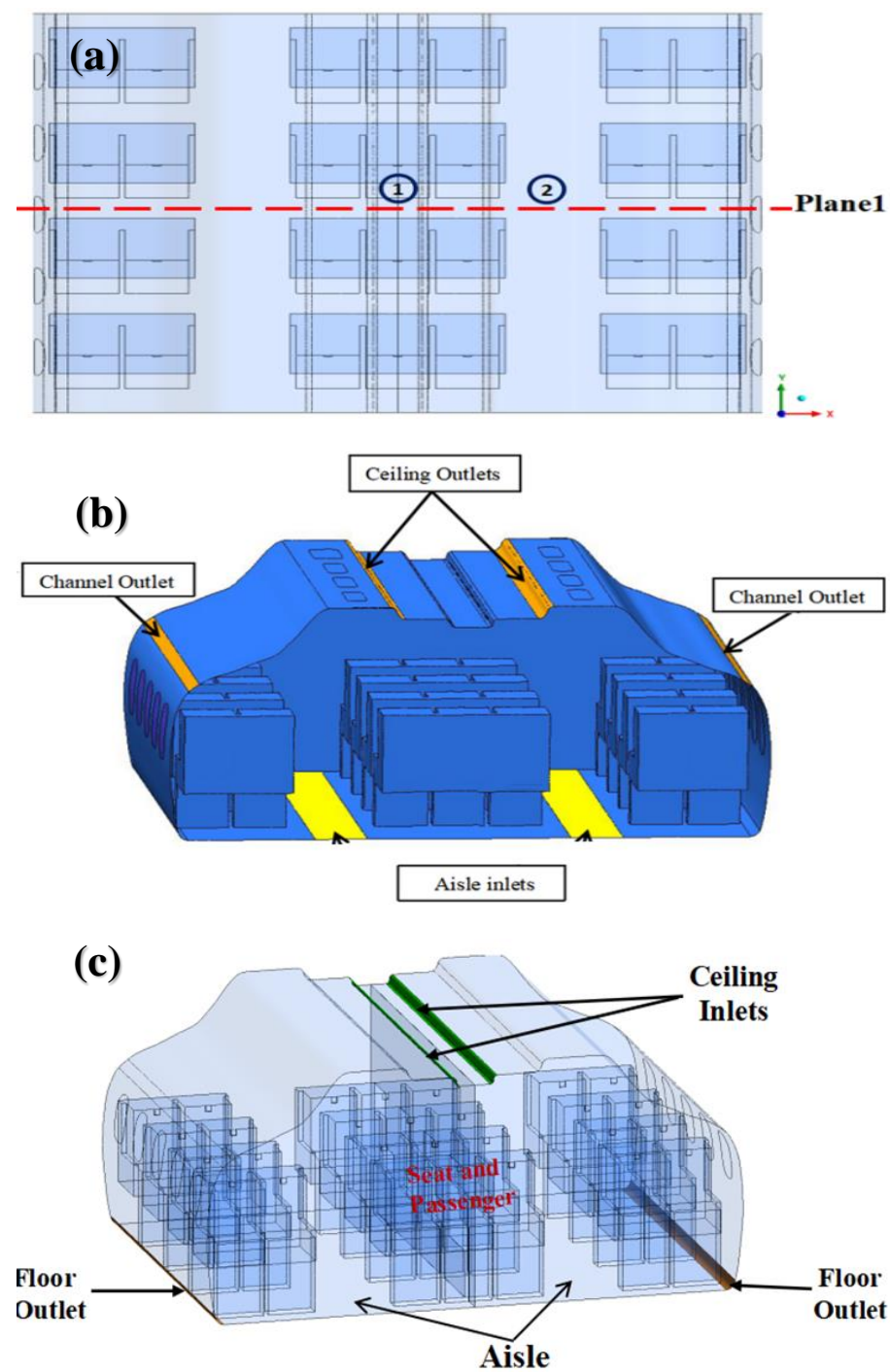

Figure 4: (a) Locations for; Plane1 $(X=3.28 \mathrm{~m})$ and positions 1 and 2; (b) Displacement ventilation system and (c): Mixing Ventilation system. 
Table 1: The boundary conditions considered for the numerical simulation of the ventilation systems

\begin{tabular}{|c|c|c|c|c|}
\hline S. No & Boundary & Boundary type & Mixing System & Displacement System \\
\hline \multirow{4}{*}{1} & \multirow{4}{*}{ Inlet } & Velocity inlet & $0.38 \mathrm{~m} / \mathrm{s}$ & $0.1 \mathrm{~m} / \mathrm{s}$ \\
\hline & & Supply flow rate & $10 \mathrm{~L} / \mathrm{s}$ & $10 \mathrm{~L} / \mathrm{s}$ \\
\hline & & Air supply temperature & $19.5^{\circ} \mathrm{C}$ & $22^{\circ} \mathrm{C}$ \\
\hline & & Water content Humidity & $0.001007 \mathrm{~kg} / \mathrm{m}^{3}$ & $0.004848 \mathrm{~kg} / \mathrm{m}^{3}$ \\
\hline 2 & Central ceiling temperature & Temperature & $25^{\circ} \mathrm{C}$ & $25.1^{\circ} \mathrm{C}$ \\
\hline 3 & Side ceiling temperature & Temperature & $23^{\circ} \mathrm{C}$ & $25.5^{\circ} \mathrm{C}$ \\
\hline 4 & Side wall temperature & Temperature & $18^{\circ} \mathrm{C}$ & $23^{\circ} \mathrm{C}$ \\
\hline 5 & Window temperature & Temperature & $13^{\circ} \mathrm{C}$ & $20^{\circ} \mathrm{C}$ \\
\hline 6 & Lighting heat generation & Heat flux & \multicolumn{2}{|c|}{$12.5 \mathrm{~W} /$ row } \\
\hline 7 & Operating pressure & \multicolumn{3}{|c|}{$77910.6 \mathrm{~Pa}-7000$ feet cabin altitude } \\
\hline 8 & Outlet & \multicolumn{3}{|c|}{ Outflow } \\
\hline 11 & Cabin Front & \multicolumn{3}{|c|}{ Symmetry } \\
\hline 12 & Cabin Rear & \multicolumn{3}{|c|}{ Symmetry } \\
\hline 13 & Floor & \multicolumn{3}{|c|}{ Wall } \\
\hline
\end{tabular}

\subsection{Mesh Independence Study}

Before initiating the simulation, the mesh independence study was performed on the mixing ventilation system, The ANSYS Fluent, being face-based now supports polyhedral cells; the polyhedral meshes has proven to keep the same spatial accuracy with a 3-5 lower cell count than the regular tetrahedral unstructured mesh. The unstructured tetra-mesh was created using the ANSYS mesh modeler, and these were converted to polyhedral one in the Fluent. Now individual each cell of the

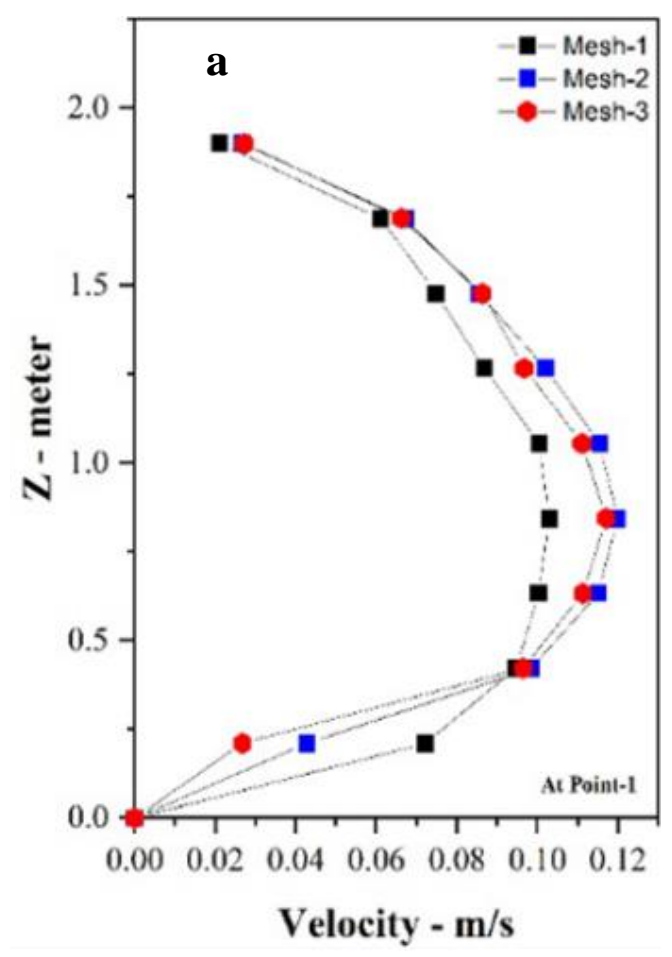

mesh will have many neighbors, which can make the gradients much better in comparison to the tetrahedral mesh. The simulation was performed with the boundary conditions mentioned in the previous section. After which the vertical velocity, temperature and relative humidity fluctuations were extracted at two different points as seen in figure 5. Figure 4-a shows the two positions where the comparisons were made from All plots bellow, it is observed that the Mesh-2 and Mesh-3 are in close relation with each other. Hence, Mesh-3 was considered for the further numerical investigations.

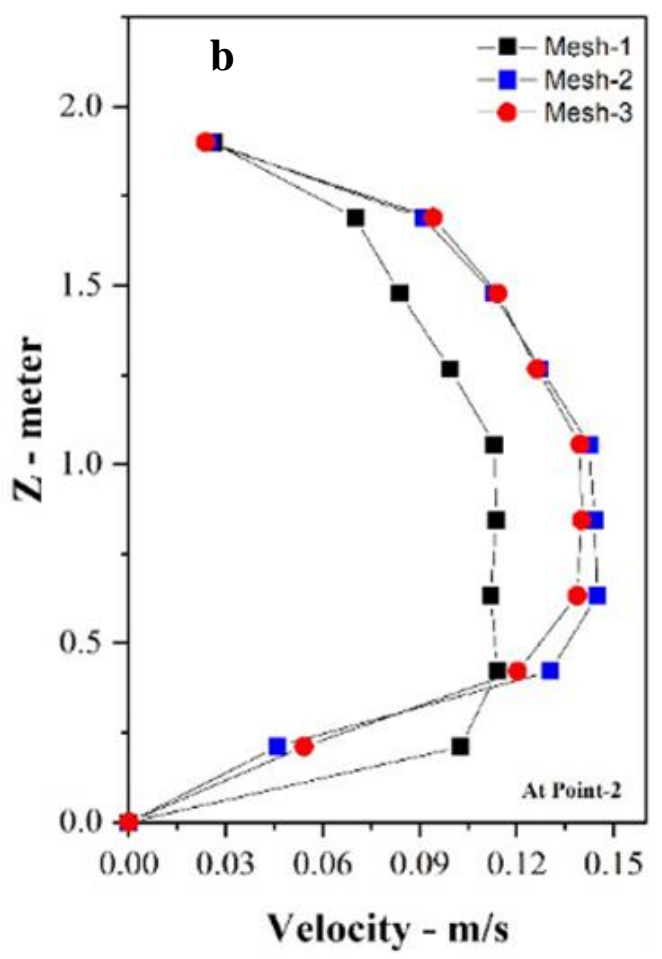




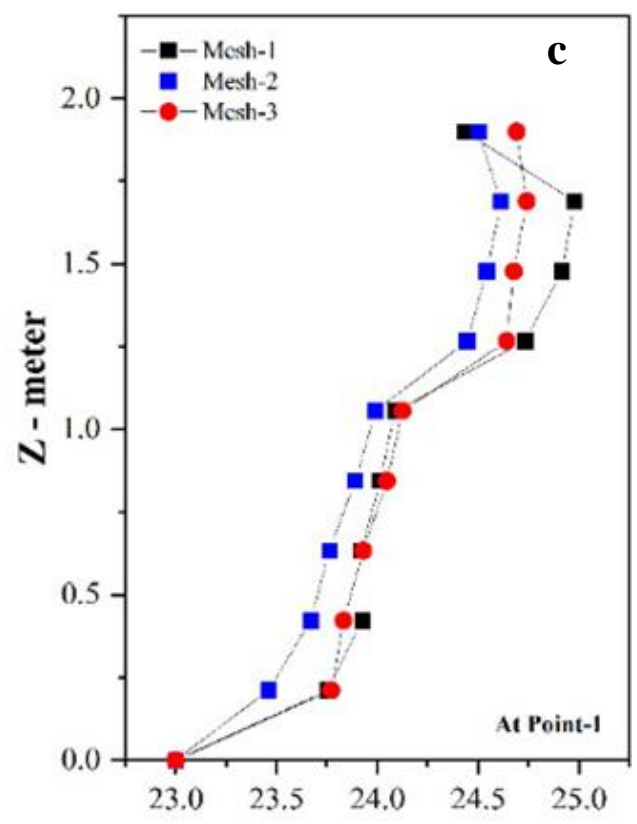

Temperature - Celsius

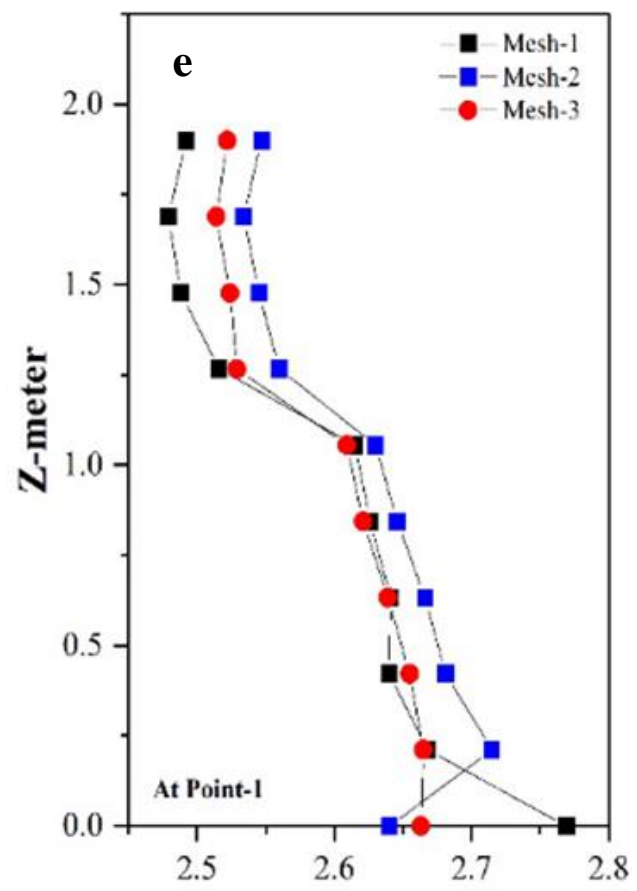

Relative Humidity-\%

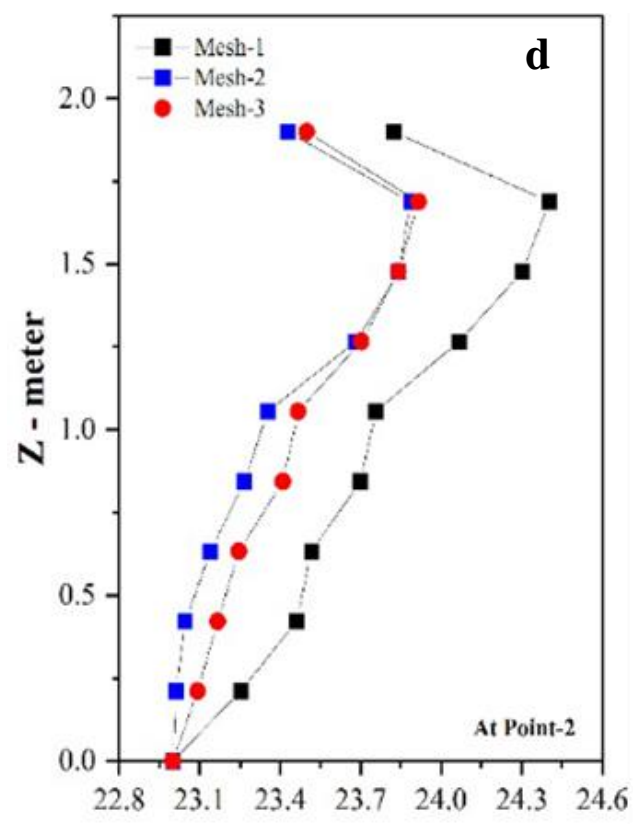

Temperature - Celsius

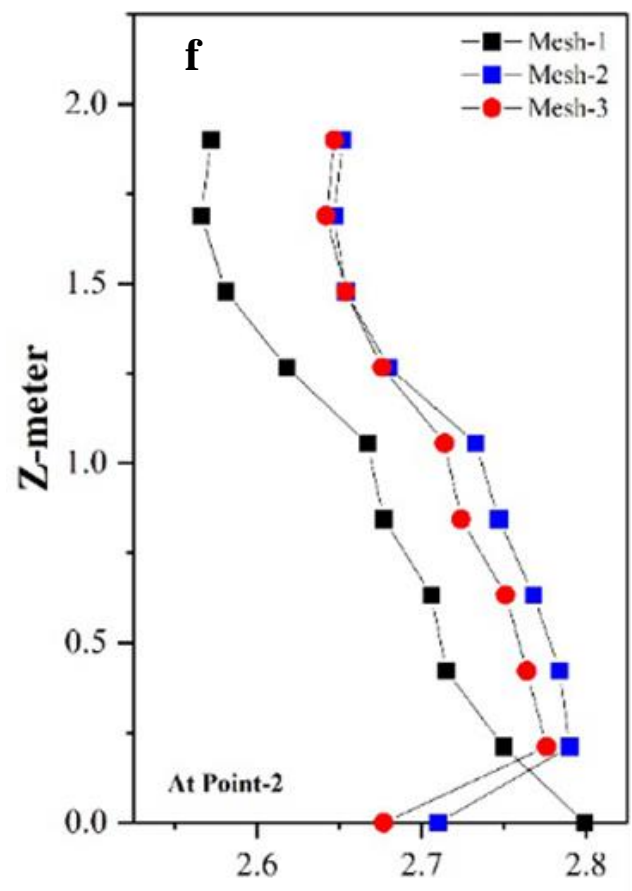

Relative Humidity-\%

Figure 5: Comparison along the height of the cabin of: (a): Velocity at position-1 ; (b): velocity at position-2 ; (c): Temperature at position-1; (d): Temperature at position-2;(e): Relative Humidity at position-1;(f): Relative Humidity at Position-2

\section{Results and Discussion}

The performance of the two air distribution systems shown in Figure $4 \mathrm{~b}-\mathrm{c}$ were compared in terms of air velocity, air temperature, Predicted Mean Vote (PMV) and Predicted Percentage Dissatisfied (PPD). The planes locations at which the measurements were taken is shown in figure 4-a. 

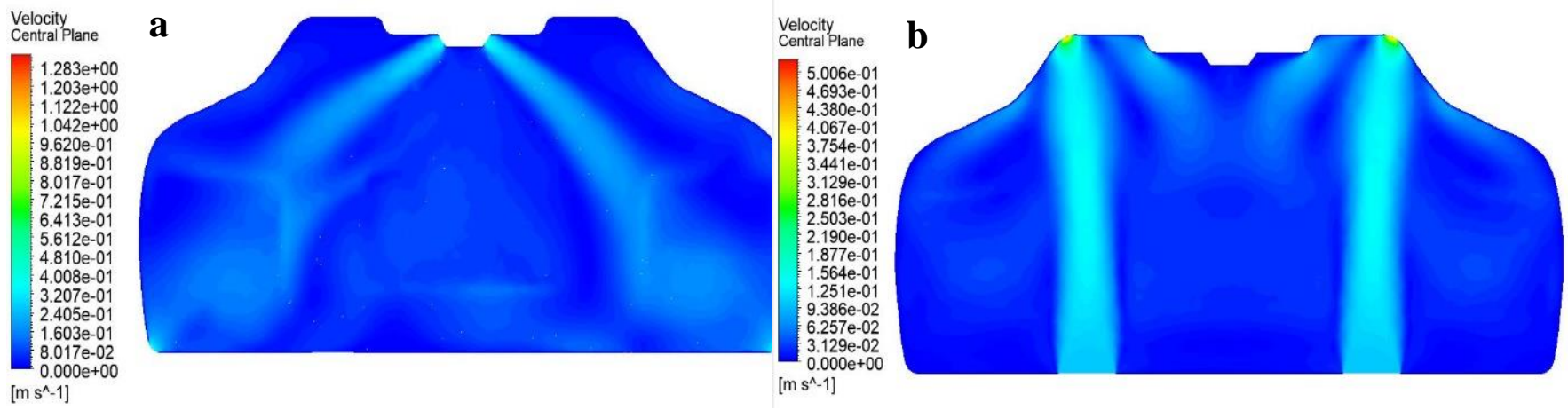

Figure 6: Velocity contours: (a): The Mixing Ventilation System and (b): Displacement Ventilation System

Figure 6(a) indicates that the mixing ventilation creates a higher air velocity than the displacement ventilation. The air temperature for mixing ventilation is much more uniform than the displacement ventilation because of mixing. See figure $7(a)$. In

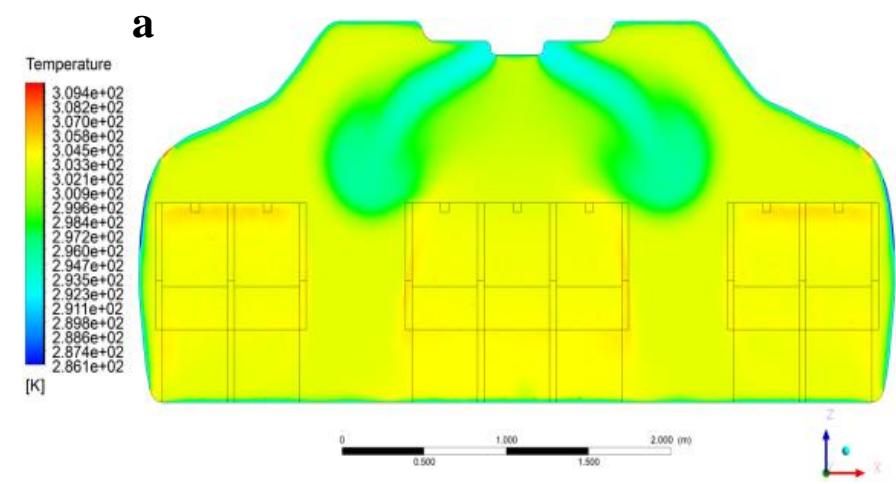

Figure 7: Temperature contours: (a): Mixing Ventilation System and (b): Displacement Ventilation system

The thermal comfort sensation is a difficult concept to quantify. It depends on a high number of parameters that have a role in the realization of a thermal balance between the human body and its environment. The dry temperature, the air velocity, the average radiant temperature and the relative humidity are the principal variables that govern the thermal comfort sensation. An adequate modeling of the thermo-aeraulic movement in buildings is very important for the evaluation of thermal comfort. This thermal comfort is often presented by the determination of the two indices of comfort: the PMV (Predicted Mean Vote) and PPD (Predicted Percentage of Dissatisfied People). These indices are introduced by (Fanger,1970) and described in the standard of the thermal comfort of American Society of Heating, Refrigerating and AirConditioning Engineers (ASHRAE,2004). To assess the Thermal comfort in the environment around the passenger, the Predicted Mean Vote (PMV) was evaluated based on 7-point ASHRAE scale. Also, the Predicted Percentage Dissatisfied (PPD) index was found to evaluate passenger comfort level by using the following formulas:

Where

$\mathrm{PMV}=\mathrm{TS} \times(\mathrm{MW}-\mathrm{HL} 1-\mathrm{HL} 3-\mathrm{HL} 4-\mathrm{HL} 5-\mathrm{HL} 6)(1)$

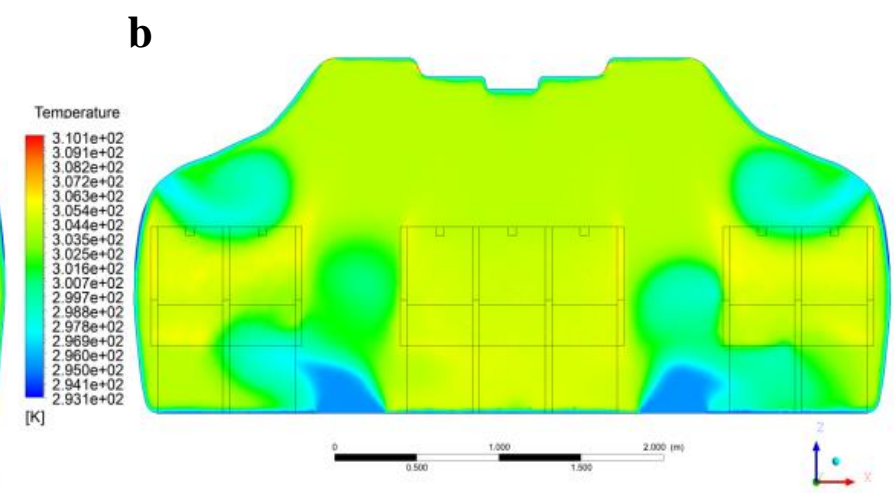

this investigation, however, the difference in air temperature between the head and ankle level of a passenger is less than $3 \mathrm{~K}$. This indicates that thermal comfort would not be a problem.

$$
\begin{aligned}
& \mathrm{HL} 1=3.05 \times 0.001 \times(5733-6.99 \times \mathrm{MW}-\mathrm{PA}) \\
& \mathrm{HL} 2=0.42 \times(\mathrm{MW}-5.8 .15) \\
& \mathrm{HL} 3=1.7 \times 0.00001 \times \mathrm{M} \times(5867-\mathrm{PA}) \\
& =0.0014 \times \mathrm{M}(34-\mathrm{TA}) \\
& \mathrm{HL} 5=3.96 \times \mathrm{FCL} \times\left(\mathrm{XN}-(\mathrm{TRA} / 100)^{4}\right) \\
& \mathrm{HL} 6=\mathrm{FCL} \times \mathrm{HC} \times(\mathrm{TCL}-\mathrm{TA}) \\
& \mathrm{FCL}=1+1.29 \times \mathrm{ICL} \mathrm{ICL} \leq 0.078 \mathrm{FCL}=1.05+0.645 \times \mathrm{ICL} \\
& \mathrm{ICL}>0.078
\end{aligned}
$$

$\mathrm{M}$ is the Metabolic Rate $\left(\mathrm{W} / \mathrm{m}^{2}\right)=58$

$\mathrm{W}$ is the effective mechanical power $\left(\mathrm{W} / \mathrm{m}^{2}\right)$

$\mathrm{ICL}=$ Clothing insulation $\left(\mathrm{m}^{2} . \mathrm{K} / \mathrm{W}\right)=0.160$

$\mathrm{FCL}=$ Clothing surface area factor

$\mathrm{TA}=$ Air Temperature $\mathrm{Tr}=$ Mean radiant temperature

$\mathrm{HC}=$ Convective Heat Transfer coefficient $=12.2$ Sqrt (VA)

$\mathrm{VA}=$ Relative Velocity $\mathrm{TCL}=$ Clothing surface temperature

$\mathrm{PPD}=100-95 \times \mathrm{EXP}\left(-0.03353 \times \mathrm{PMV}^{4}-0.2179 \times \mathrm{PMV}^{2}\right)(2)$ 
Table 2: PMV and PPD Calculation for the mixing ventilation

\begin{tabular}{|l|l|}
\hline Mixing Ventilation System & 20.5 \\
\hline Air Temperature & 0.01 \\
\hline Air Speed & $4.60 \%$ \\
\hline Relative Humidity & 1 \\
\hline Metabolic Rate & 1 \\
\hline Clothing Level & -1.14 \\
\hline PMV & $32 \%$ \\
\hline PPD & Slightly Cool \\
\hline Sensation
\end{tabular}

Table 3: PMV and PPD Calculation for the displacement ventilation

\begin{tabular}{|l|l|}
\hline Displacement Ventilation System \\
\hline Air Temperature & 22.7 \\
\hline Mean Radiant Temperature & 22 \\
\hline Air Speed & 0.03 \\
\hline Relative Humidity & $11.60 \%$ \\
\hline Metabolic Rate & 1 \\
\hline Clothing Level & 1 \\
\hline PMV & -0.48 \\
\hline PPD & $10 \%$ \\
\hline Sensation & Neutral \\
\hline
\end{tabular}

PMV is an index that predicts the mean value of votes of the group of occupants on the thermal sensation scale. The heat balance in any environment is influenced by physical activity, clothing insulation, air temperature, velocity of air, the quantity of humidity in air. PPD is the level of satisfaction of those occupants in space, it is generally required to identify the percentage of dissatisfied occupants/passengers in the room. The air temperature, humidity and air speed near the region of the passenger were considered and the PMV and PPD were found using the Center for the Built Environment Thermal Comfort Tool. The PMV and PPD for each of the mixing and displacement ventilation systems were found and tabulated in the table 2 and table 3. It is observed that the PMV and PPD for the Mixing ventilation system were high in comparison with the displacement. The sensation for the displacement was Neutral, whereas the sensation in the mixing system was slightly cool. The humid air content supplied from the personal inlet vent created a satisfactory micro environment for the passenger.

\section{Conclusions}

By using the experimental data obtained from a small office with displacement ventilation and the results obtained from our numerical investigations, this paper shows that the investigators are capable of using FLUENT to correctly calculate airflow in an enclosed environment. FLUENT was used to simulate airflow in a section of an aircraft cabin with two ventilation systems: mixing and under-floor displacement. The results show that the mixing ventilation system generally has a higher air velocity than the under-floor displacement system and more uniform air temperature. Air temperature is stratified in the cabin with displacement. It is observed that the PMV and PPD for the Mixing ventilation system were high in comparison with the displacement. The sensation for the displacement was Neutral, whereas the sensation in the mixing system was slightly cool. The humid air content supplied from the personal inlet vent created a satisfactory micro environment for the passenger. Based on the results of this analysis, it is recommended that the mixing ventilation system be potentially used for commercial aircraft cabins and it observed that the locations of inlets affect the thermal comfort, as it gets nearer to the passenger the thermal comfort feelings improves. This research also recommends a suitable personalized ventilation system for future commercial aircraft cabin.

\section{Conflict of interest statement}

Authors declare that they have no conflict of interest

\section{Acknowledgment}

Authors thank their colleagues for their helpful suggestions

\section{References}

[1] National Academy of Sciences, "Environment and the Health of Passengers and Crew." 2002.

[2] Ryan,E.T., Wilson,M.E., and Kain,K.C., "Illness After International Travel,” English J., vol. 347, no. 7, 2011.

[3] Mangili, A. and Gendreau, M. , "Transmission of infectious diseases during commercial air travel," Lancet, vol. 365, no. 9463, 2005.

[4] NRC. 2001. The Airliner Cabin Environment and the Health of Passengers and Crew. Washington, DC: National Academy Press.

[5] Hunt, E. H., Reid, D. H., Space, D. R., and Tilton, F. E., "Commercial airliner environmental control system," Proc. Aerosp. Med. Assoc. Annu. Meet. Anaheim USA, 1995.

[6] Zhang, T. and Chen, Q. (Yan), "Novel air distribution systems for commercial aircraft cabins," Building and Environment, vol. 42, no. 4, 2007.

[7] AIAA, "Guide for the Verification and Validation of Computational Fluid Dynamics Simulations," AIAA, vol. 1998, 1998.

[8] Aboosaidi F, Warfield M, and Choudhury D. 1991. "Computational fluid dynamics applications in airplane cabin ventilation system design," Proceedings - Society of Automotive Engineers. 246: 249-258

[9] Garner R., Wong K., Ericson S. and Baker A. 2003. "CFD validation for contaminant transport in aircraft cabin ventilation flow fields," Proceedings - Annual SAFE Symposium (Survival and Flight Equipment Association). 2003, 248-253.

[10] Chen Q. and Srebric J. 2002. "A procedure for verification, validation and reporting of indoor environment CFD analyses," HVAC\&R Research. 8 (2): 201-216.

[11] Yuan X., Chen Q., Glicksman L., Hu Y. and Yang X. 1999. "Measurements and computations of room airflow with displacement ventilation," ASHRAE Transactions. 105 (1): 340-352.

[12] Yakhot V., Orzag SA., Thangam S., Gatski TB. and Speziale CG. 1992. Development of turbulence models for shear flows by a double expansion technique. Phys. Fluids A. 4(7), 1510-1520.

[13] Srebric J. and Chen Q. 2002. "An example of verification, validation, and reporting of indoor environment CFD analyses," ASHRAE Transactions. 108 (2): 185-194.

[14] Topp C., Nielsen P. and Sorensen D. 2002 . "Application of computer simulated persons in indoor environmental modelling," ASHRAE Transactions. 108 (2): 1084-1089.

[15] P.O. Fanger, Thermal Comfort, McGraw-Hill, New York, 1970.

[16] ANSI/ASHRAE Standard 55, Thermal Environment Conditions for Human Occupancy, ASHRAE, Atlanta, 2004.

Cite this article as: Chanfiou Ahmed Mboreha, Somashekar V, Gaurav Kumar, Collins Nwaokocha, Abayomi Layenil, Comparative study of mixing and under-flow air distribution system in an aircraft cabin using CFD, International Journal of Research in Engineering and Innovation Vol-4, Issue-5 (2020), 280-286. https://doi.org/10.36037/IJREI.2020.4507 